\title{
OPTIMIZATION AND ECONOMIC ANALYSIS OF MULTIPRODUCTS OBTAINED FROM WOOD OF EUCALYPTUS STANDS UNDER DIFFERENT PRODUCTIVE CAPACITY CLASSES AND ROTATION AGES
}

\author{
Laíssa de Araújo Viana ${ }^{1}$, Renato Vinícius Oliveira $\mathrm{Castro}^{2}$, Álvaro Nogueira de Souza ${ }^{3}$, Carlos Pedro Boechat \\ Soares $^{4}$, Maísa Santos Joaquim ${ }^{5}$, Lidiomar Soares da Costa ${ }^{6 *}$ \\ ${ }^{1}$ Instituto Estadual de Florestas - IEF, Januária, MG, Brasil - laissav@ gmail.com \\ ${ }^{2}$ Universidade Federal de São João del-Rey, Departamento de Engenharia Florestal, Sete Lagoas, Minas Gerais, Brasil - \\ castrorvo@ymail.com \\ ${ }^{3}$ Universidade de Brasília, Departamento de Engenharia Florestal, Brasília, DF, Brasil - ansouza@unb.br \\ ${ }^{4}$ Universidade Federal de Viçosa, Departamento de Engenharia Florestal, Viçosa, MG, Brasil - csoares@ufv.br \\ ${ }^{5}$ Universidade de Brasília, Faculdade de Agronomia e Medicina Veterinária, Brasília, DF, Brasil - maisaunb@gmail.com \\ ${ }^{6}$ Universidade Federal de Uberlândia, Instituto de Ciências Agrárias, Monte Carmelo, Minas Gerais, Brasil - lidiomar.ef@gmail.com*
}

Received for publication: 04/12/2018 - accepted for publication: 15/12/2020

\begin{abstract}
Resumo
Otimização e análise econômica de multiprodutos da madeira de eucalipto sob diferentes classes de capacidade produtiva e idades de rotação. O presente estudo teve como objetivo analisar o rendimento e a viabilidade econômica da destinação para serraria e energia, da madeira proveniente de povoamentos não desbastados de Eucalyptus urophylla x Eucalyptus grandis em diferentes classes produtivas e que cuja produção foi projetada por modelo de árvores individuais para diferentes idades. A simulação do crescimento das árvores individuais foi realizada aplicando-se submodelos de mortalidade e de crescimento em altura e diâmetro, para três classes de capacidade produtiva: alta, média e baixa. Para estudo do afilamento dos fustes e a otimização do corte ajustou-se o modelo de Kozak. A viabilidade econômica dos projetos foi avaliada por meio do Valor Presente Líquido, Benefício Periódico Equivalente e análise de risco utilizando método de Monte Carlo. Observou-se que em áreas de menor capacidade produtiva o volume destinado para energia foi superior a $80 \%$ e em áreas de maior capacidade produtiva o volume em peças de madeira serrada foi superior a $26 \%$. Os indicadores econômicos mostraram que a destinação da madeira para serraria foi viável em qualquer das idades estudadas. A análise de risco pelo método de Monte Carlo não indicou possibilidade de inviabilidade do projeto sob as condições analisadas. A quantidade de diferentes tipos de produtos obtidos e o rendimento da madeira foi dependente da classe de capacidade produtiva e idade do povoamento. A destinação da madeira para multiprodutos foi a opção mais viável, independentemente da classe de capacidade produtiva.

Palavras-chave: Viabilidade econômica, sortimento de madeira, sítios florestais, idade de colheita
\end{abstract}

\begin{abstract}
The present study aimed to analyze the yield and economic viability of the destination, for lumber and energy, of the wood from non-thinned stands of the hybrid Eucalyptus urophylla x Eucalyptus grandis under different productive capacity class and whose production was projected by individual tree growth model to different ages. The simulation of the growth of individual trees was performed by applying the height and diameter growth, and mortality sub-models for three productive capacity classes: high, medium and low. The Kozak model was adjusted to study the stem taper and, in addition, used to optimize patterns for sawing logs and to produce lumber. The economic viability of the projects was evaluated by Net Present Value, Equivalent Periodic Benefit and risk analysis using the Monte Carlo method. It was observed that in areas with less productive capacity the volume of wood destined for energy was greater than $80 \%$ and, in areas with greater productive capacity the volume of lumber was greater than $26 \%$. Economic indicators showed that the lumber production was viable at any of the studied rotation age. The risk analysis using the Monte Carlo method did not indicate the possibility of the project being unfeasible under the conditions analyzed. The quantity of different types of products obtained and the wood yield depends on the productive capacity class and age of the stand. The destination of the wood for multiproducts is the most viable option, regardless of the productive capacity class.
\end{abstract}

Keywords: Economic viability, wood assortment, forest sites, harvest age

\section{INTRODUCTION}

Eucalyptus, due to its timber potential and high growth rates (STAPE et al., 2010), is the forest genus with the largest planted area in Brazil, occupying an area of 5.67 million hectares, which represents $72.3 \%$ of reforested areas (IBÁ, 2017). When it was introduced in the country, eucalyptus was used only as firewood, fence posts and railroad ties, however, it is currently characterized by the supply of a great diversity of products, such as: charcoal, firewood, paper and cellulose, panels, furniture, laminates, fence posts, props, wainscoting, oil for the production of medicines, cosmetics and food products, among others (IBÁ, 2017).

FLORESTA, Curitiba, PR, v. 51, n. 2, p. 293-302, abril/jun 2021.

Viana, L. A. et.al.

ISSN eletrônico 1982-4688

DOI: $10.5380 /$ rf.v51 i2. 63729 
This multiplicity of uses allows the forest producer greater flexibility regarding the commercialization of products that have different market values. In addition, variations in demand over the years, especially for small and medium-sized producers, can guarantee greater profitability and lower risks in the commercialization of forest production (SOARES et al., 2003).

Obtaining multiple products from the production forests necessarily requires knowledge of the characteristics of the stands with regard to the growth rate and the shape of the tree stems, as well as the factors that affect these variables (ASSIS et al., 2002). Both are influenced, among other factors, by the productive capacity of the site (CAMPOS; LEITE, 2017; FIGUEIREDO FILHO et al., 2014). In places of low productive capacity, trees usually have greater taper or undesirable shapes. In these sites, the height growth for trees of the same diameter is smaller and, as a consequence, the stem is more tapered (FIGUEIREDO FILHO et al., 2014).

Given the diversity of assortments that can be produced, it is necessary to carry out an economic analysis to decide which is the best alternative for the destination of the wood to be adopted. This diagnosis is based on the use of analysis techniques and criteria that can compare the costs and revenues relevant to the investment. Among the most applied methods in the forestry area, the following stand out: Net Present Value, Internal Rate of Return and Equivalent Periodic Benefit (REZENDE; OLIVEIRA, 2013).

Many studies have been carried out for the economic analysis of obtaining multiproducts from forest stands (PAVAN et al., 2010; CASTRO et al., 2011; FOLMANN et al., 2013; LUSTOSA JÚNIOR et al., 2017), however, there are no studies that assess the feasibility of obtaining multiproducts of wood depending on the productive capacity of the site. Thus, the objective of the present study was to carry out an analysis of the yield and economic viability of the destination for lumber and energy, of the wood coming from stands of Eucalyptus urophylla x Eucalyptus grandis not thinned under different productive capacity class and whose production was projected by individual tree growth model for different ages.

\section{MATERIAL AND METHODS}

This study was based on the data from non-thinned stands of clones of the hybrid Eucalyptus urophylla x Eucalyptus grandis, established at an initial spacing of $3.0 \mathrm{~m} \mathrm{x} 3.0 \mathrm{~m}$ and located in the municipality of Monte Dourado, in the State of Pará. The climate of the region is Am type, according to the Köppen classification, with an average annual rainfall of $2,115 \mathrm{~mm}$ and is characterized by short dry season between September and November. The average annual temperature is $26.4^{\circ} \mathrm{C}$ and the average relative humidity varies from 80 to $85 \%$ (DEMOLINARI et al., 2007).

The data were obtained from 63 rectangular permanent plots $500 \mathrm{~m}^{2}$ in size, each plot was measured on five annual occasions, from 24 to 72 months. On each occasion, considering trees with a diameter at $1.30 \mathrm{~m}$ (diameter at breast height, DBH) greater than or equal to $4.0 \mathrm{~cm}$, the $\mathrm{DBH}$; the total height (Ht) of the first 15 trees; and the total height of the five dominant trees (Hd) were measured in each plot.

The classification of the productive capacity was performed using the equation adjusted by Demolinari et al. (2007) for the same study area:

$$
\text { LnHd }=3.510492274-14.88011596 . I^{-1} \quad R^{2}=0.4995 \quad \text { CV\% }= \pm 9.68 \%
$$

where: $\mathrm{Ln}$ is the neperian logarithm; Hd is the dominant height (m); $S$ is the location index (m); I is the age of the stand (months); $\mathrm{I}_{\mathrm{i}}$ is the index age (60 months).

The productive capacity classes were then defined as: high (S32), with Hd $>29.0 \mathrm{~m}$; medium (S26) with $23.0<\mathrm{Hd} \leq 29.0 \mathrm{~m}$; and low (S20) with $\mathrm{Hd} \leq 23.0 \mathrm{~m}$, at the index age of 60 months.

The data from each plot at 72 months were used to project the DBH and Ht up to 120 months, at 12month intervals. For that, a complete model at the individual tree level was used in a projection structure of the variables, at a current age for a future age $(\mathrm{t} \rightarrow \mathrm{t}+1)$, adjusted for the study area by Martins et al. (2014). The equations were developed for each productive capacity classes:

$$
\begin{array}{llll}
\mathrm{S} 32 & D B H_{2}=-1.200180+0.853270 S\left(\frac{D B H_{1}}{-1.200180+0.853270 S}\right)^{\left(\frac{I_{1}}{I_{2}}\right)^{0.107830}} & \mathrm{R}^{2}=0.99 & \mathrm{~S}_{\mathrm{yx}}= \pm 3.03 \\
\mathrm{~S} 26 & D B H_{2}=-0.915365+1.173732 S\left(\frac{D B H_{1}}{-0.915365+1.173732 S}\right)^{\left(\frac{I_{1}}{I_{2}}\right)^{0.130767}} & \mathrm{R}^{2}=0.98 & \mathrm{~S}_{\mathrm{yx}}= \pm 3.48 \\
\mathrm{~S} 20 \quad D B H_{2}=-0.530658+1.152842 S\left(\frac{D B H_{1}}{-0.530658+1.152842 S}\right)^{\left(\frac{I_{1}}{I_{2}}\right)^{0.117852}} & \mathrm{R}^{2}=0.97 & \mathrm{~S}_{\mathrm{yx}}= \pm 4.39
\end{array}
$$




$$
\begin{array}{llll}
\mathrm{S} 32 & H t_{2}=0.311642+0.138940 S\left(\frac{H t_{1}}{0.311642+0.138940 S}\right)^{\left(\frac{I_{1}}{I_{2}}\right)^{0.411735}} & \mathrm{R}^{2}=0.99 & \mathrm{~S}_{\mathrm{yx}}= \pm 2.00 \\
\mathrm{~S} 26 & H t_{2}=0.387227+0.233971 S\left(\frac{H t_{1}}{0.387227+0.233971 S}\right)^{\left(\frac{I_{1}}{I_{2}}\right)^{0.341151}} & \mathrm{R}^{2}=0.99 & \mathrm{~S}_{\mathrm{yx}}= \pm 2.53 \\
\mathrm{~S} 20 & H t_{2}=0.70028+0.163913 S\left(\frac{H t_{1}}{0.70028+0.163913 S}\right)^{\left(\frac{I_{1}}{I_{2}}\right)^{0.403665}} & \mathrm{R}^{2}=0.97 & \mathrm{~S}_{\mathrm{yx}}= \pm 3.25
\end{array}
$$

where: $I_{1}$ and $I_{2}$ are the current (1) and future (2) ages (months); $\mathrm{DBH}_{1}$ and $\mathrm{DBH}_{2}$ are the diameters at breast height in the current (1) and future (2) ages (cm); $\mathrm{Ht}_{1}$ and $\mathrm{Ht}_{2}$ are the total heights in the current (1) and future (2) ages $(\mathrm{m})$; $\mathrm{S}$ is the location index.

For the simulation of tree mortality, the following model was applied to all productive capacity classes, in which estimates are made for the DBH classes using an independent distance competition index (IID):

$$
P(M)=0.038163 B A I^{-0.287461} \quad \mathrm{R}^{2}=0.5715 \quad \mathrm{~S}_{\mathrm{yx}}= \pm 52.5
$$

where: $\mathrm{BAI}$ is the IID $=\mathrm{di}^{2} / \mathrm{q}^{2} ; \mathrm{d}_{\mathrm{i}}$ is DBH class center $(\mathrm{cm})$; $\mathrm{q}$ is quadratic mean DBH $(\mathrm{cm})$.

The simulation of the growth of individual trees was performed by simultaneously applying the height and diameter growth, and mortality sub-models, using an application developed in a Visual Basic for Applications environment - Microsoft Excel ${ }^{\circledR}$, version 2007.

The mortality rate and height and diameter growth were projected annually from an initial age of 72 months to an age of 120 months. The entry of new trees in the projection period was not considered. This simulation was performed 10 times for each productive capacity class and age of prognosis.

The Kozak model was selected as the most suitable for simulating the stem taper. Like the previously mentioned model, taper models allow to define the height and diameter at any point of the stem. The equation obtained from the adjustment of the referred model is presented below.

$$
\text { Kozak } \quad d=D B H \sqrt{1.0560216-1.7932137\left(\frac{h}{H t}\right)+0.7385050\left(\frac{h}{H t}\right)^{2}} \quad R^{2}=0.99
$$

where: $h$ is the height at any point of the bole (m); Ht is the total height (m); $d$ is the diameter with bark at height $\mathrm{h}(\mathrm{cm})$; DBH is the diameter with bark at $1.30 \mathrm{~m}$ high $(\mathrm{cm})$.

The equation was inserted in the SigmaE software (LEITE et al., 1995) for the optimization of trees in multiproducts. Using dynamic programming, this software allows to optimize patterns for sawing logs and producing lumber with certain dimensions based on the costs for obtaining them and their respective market values (Tables 1 and 2), assuming the existence of demand.

The costs of the operations considered in this study are described in Table 1, which were raised based on the prices of implementing and conducting forestry experiments with this spacing and slope conditions. To calculate the market value of bare land, information from forest producers, chosen at random, was used as a source. The average value of land considered for the region was $\mathrm{R} \$ 2,800.00 / \mathrm{ha}$. The cost of the land factor was considered by the method of interest on the value of the land, because, according to Silva et al. (2008), provides results more

\begin{tabular}{|c|c|c|c|}
\hline Stage/Activity & Year & Value & Unit \\
\hline Land cost & 1 to $n^{1 /}$ & $2,800.00$ & $\mathrm{R} \$ . \mathrm{ha}^{-1}$ \\
\hline Forest implementation & 0 & $2,689.50$ & $\mathrm{R} \$ . \mathrm{ha}^{-1}$ \\
\hline Maintenance & 1 & 854.00 & $\mathrm{R} \$ . \mathrm{ha}^{-1}$ \\
\hline Maintenance & 2 & 654.00 & $\mathrm{R} \$ . \mathrm{ha}^{-1}$ \\
\hline Maintenance & 3 to $n$ & 404.00 & $\mathrm{R} \$ . \mathrm{ha}^{-1}$ \\
\hline Administration & 1 to $n$ & 190.00 & $\mathrm{R} \$ . \mathrm{ha}^{-1}$ \\
\hline Pre-cut mowing & $\mathrm{n}$ & 120.00 & $\mathrm{R} \$ . \mathrm{ha}^{-1}$ \\
\hline Harvest and transportation & $\mathrm{n}$ & 19.00 & $\mathrm{R} \$ \cdot \mathrm{m}^{-3}$ \\
\hline Licenses and fees & 0 and $n$ & 200.00 & $\mathrm{R} \$ . \mathrm{ha}^{-1}$ \\
\hline
\end{tabular}
consistent with market values.

Table 1. Average costs of the different stages and activities carried out in a non-thinned stands of the hybrid Eucalyptus urophylla $\mathrm{x}$ Eucalyptus grandis under different productive capacity class and considering the harvest ages at 72, 84, 96, 108 and 120 months.

Tabela 1. Custos médios das diferentes etapas e atividades realizadas em povoamento não desbastado do híbrido Eucalyptus urophylla x Eucalyptus grandis sob diferentes classes de capacidade produtiva e considerando as idades de colheita aos 72, 84, 96, 108 e 120 meses.

${ }^{1 /} n$ is the last year of the project

FLORESTA, Curitiba, PR, v. 51, n. 2, p. 293-302, abril/jun 2021.

Viana, L. A. et.al.

ISSN eletrônico 1982-4688

DOI: $10.5380 /$ rf.v51 i2. 63729 
Two types of wood destination were selected: energy production and lumber. Then, SigmaE was used to simulate the optimal cut of the stems (into logs) based on the products to be obtained from the wood and their respective dimensions, transformation costs and market values (Tables 2 and 3). This software uses dynamic programming and allows to simulate the best use of each part of the tree, as presented by Leite et al. (1995).

Table 2. Dimensions of logs obtained from non-thinned stands of the hybrid Eucalyptus urophylla $\mathrm{x}$ Eucalyptus grandis under different productive capacity class, and used for energy and lumber, considering the harvest age at 72, 84, 96, 108 and 120 months.

Tabela 2. Dimensões das toras provenientes de povoamento não desbastado do híbrido Eucalyptus urophylla $\mathrm{x}$ Eucalyptus grandis sob diferentes classes de capacidade produtiva e destinadas para energia e à obtenção de peças de serraria considerando a idade de colheita aos 72, 84, 96, 108 e 120 meses.

\begin{tabular}{ccccc}
\hline Assortment & $\begin{array}{c}\text { Minimum length } \\
(\mathbf{c m})\end{array}$ & $\begin{array}{c}\text { Minimum } \\
\text { diameter }(\mathbf{c m})\end{array}$ & $\begin{array}{c}\text { Maximum } \\
\text { diameter }(\mathbf{c m})\end{array}$ & Price \\
\hline Energy & 250 & 4 & 25 & $45.00\left(\mathrm{R} \$ \cdot \mathrm{m}^{-3}\right)$ \\
Lumber & 300 & 20 & 200 & - Table $3-$ \\
\hline
\end{tabular}

Table 3. Dimensions and prices of lumber pieces to be obtained from the non-thinned stands of the hybrid Eucalyptus urophylla $\mathrm{x}$ Eucalyptus grandis under different productive capacity class and considering the harvest age at 72, 84, 96, 108 and 120 months.

Tabela 3. Dimensões e preços de peças madeira serrada a serem obtidas da de povoamento não desbastado do híbrido Eucalyptus urophylla x Eucalyptus grandis sob diferentes classes de capacidade produtiva considerando a idade de colheita aos 72, 84, 96, 108 e 120 meses.

\begin{tabular}{ccc}
\hline Piece & Dimensions $(\mathbf{c m} \times \mathbf{~ c m ~ x ~ c m})^{*}$ & ${\text { Price }\left(\mathbf{R} \mathbf{\$} . \mathbf{m}^{-1}\right)^{* * *}}^{\text {Slat }}$ \\
Rafter & $1.0 \times 5.0 \times 300.0$ & 0.27 \\
Beam 1 & $5.0 \times 6.0 \times 300.0$ & 1.60 \\
Beam 2 & $6.0 \times 12.0 \times 300.0$ & 3.95 \\
Batten & $6.0 \times 16.0 \times 300.0$ & 5.26 \\
Board 1 & $2.5 \times 10.0 \times 300.0$ & 1.12 \\
Board 2 & $2.5 \times 15.0 \times 300.0$ & 2.11 \\
Board 3 & $2.5 \times 20.0 \times 300.0$ & 2.98 \\
Board 4 & $2.5 \times 25.0 \times 300.0$ & 4.24 \\
\hline
\end{tabular}

${ }^{\bar{*}}$ Thickness $\mathrm{x}$ Width $\mathrm{x}$ Length; ${ }^{* *}$ Discounting the transformation cost.

The cash flow statement for the forestry project was carried out with the simulated costs of the project and the revenue, defined by the price of the products multiplied by the volume or solid piece at each projection age and in each productive capacity class. The feasibility of the projects, considering an interest rate of $8.0 \%$ p.a., was assessed using the Net Present Value (NPV) and the Equivalent Periodic Benefit (BPE), defined according to Rezende and Oliveira (2013).

The risk analysis was performed using the Monte Carlo method, using Microsoft Excel ${ }^{\circledR}$ version 2007, following the steps established by Viana et al. (2013). 5,000 iterations were performed, considering the implementation cost and the interest rate as input variables, considering variations between -30 and $+30 \%$ in these variables, considering that both variables were distributed following the normal distribution. The NPV and BPE were taken as output variables. Percentile values were generated for the simulation.

\section{RESULTS}

The estimates of quadratic mean DBH, total height, stand density and total volume projected for each productive capacity class between the ages of 72 and 120 months are shown in Table 4, as well as the yield and type of wood destination.

It is worth noting that, although the yield in pieces or logs is higher in areas of the S20 class (lower productivity), in any of the harvest ages the volume destined for less noble use (energy) was greater than $81.0 \%$. For class S32 (higher productivity), the volume lumber was greater than $26.0 \%$ in all harvest ages considered (Table 4). The nobler use, consequently, reduces the total yield of the bole due to losses during the process of cutting the logs into smaller pieces, generating the residues, which hardly occur in the tree cutting to produce firewood (for energy) 
Table 4. Quadratic mean DBH (q), total height (Ht), stand density (N) and volume per hectare (V) of non-thinned stands of the hybrid Eucalyptus urophylla x Eucalyptus grandis under different productive capacity class and the respective wood yields for energy and lumber at 72, 84, 96, 108 and 120 months.

Tabela 4. Diâmetro médio (q), altura total $(\mathrm{Ht})$, densidade $(\mathrm{N})$ e volume por hectare $(\mathrm{V})$ de povoamento não desbastado do híbrido Eucalyptus urophylla x Eucalyptus grandis sob diferentes classes de capacidade produtiva e os respectivos rendimentos de madeira em peças serradas e energia aos 72, 84, 96, 108 e 120 meses.

\begin{tabular}{|c|c|c|c|c|c|c|c|c|}
\hline \multirow{2}{*}{ Productive Class } & \multirow{2}{*}{$\begin{array}{c}\text { Age } \\
\text { (months) }\end{array}$} & \multirow{2}{*}{$\frac{q}{(\mathbf{c m})}$} & \multirow{2}{*}{$\begin{array}{l}\text { Ht } \\
(\mathrm{m})\end{array}$} & \multirow{2}{*}{$\begin{array}{c}\mathbf{N} \\
\left.\text { tree.ha' }^{-1}\right)\end{array}$} & \multirow{2}{*}{$\begin{array}{c}\mathrm{V} \\
\left(\mathrm{m}^{3} \cdot \mathbf{h a}^{-1}\right)\end{array}$} & \multirow{2}{*}{ Yield (\%) } & \multicolumn{2}{|c|}{ Use (\% of the yield) } \\
\hline & & & & & & & Lumber & Energy \\
\hline \multirow{5}{*}{ S32 } & 72 & 16.2 & 24.5 & 1050 & 296.1 & 91.5 & 26.4 & 73.6 \\
\hline & 84 & 17.2 & 26.4 & 957 & 335.0 & 90.5 & 29.3 & 70.7 \\
\hline & 96 & 17.7 & 27.0 & 955 & 369.7 & 88.7 & 32.9 & 67.1 \\
\hline & 108 & 18.1 & 27.4 & 954 & 400.1 & 87.1 & 36.6 & 63.4 \\
\hline & 120 & 18.5 & 27.6 & 953 & 426.6 & 86.5 & 37.5 & 62.5 \\
\hline \multirow{5}{*}{ S26 } & 72 & 14.2 & 22.2 & 1102 & 229.3 & 93.4 & 21.0 & 79.0 \\
\hline & 84 & 15.4 & 24.3 & 998 & 268.2 & 91.7 & 24.8 & 75.2 \\
\hline & 96 & 16.0 & 25.2 & 990 & 304.5 & 90.6 & 28.7 & 71.3 \\
\hline & 108 & 16.4 & 25.9 & 984 & 338.1 & 89.3 & 31.8 & 68.2 \\
\hline & 120 & 16.9 & 26.4 & 981 & 369.6 & 88.2 & 34.1 & 65.9 \\
\hline \multirow{5}{*}{ S20 } & 72 & 11.1 & 18.0 & 1087 & 114.0 & 97.4 & 9.3 & 90.7 \\
\hline & 84 & 12.2 & 20.2 & 965 & 133.1 & 96.7 & 11.4 & 88.6 \\
\hline & 96 & 12.6 & 21.2 & 956 & 152.0 & 95.7 & 14.0 & 86.0 \\
\hline & 108 & 12.9 & 22.1 & 951 & 170.7 & 95.1 & 16.2 & 83.8 \\
\hline & 120 & 13.2 & 22.9 & 947 & 189.1 & 94.3 & 18.4 & 81.6 \\
\hline
\end{tabular}

Analyzing the destination of wood for multiproducts by age and by diameter class, it was observed that areas of high and medium productive capacity (S32 and S26) provided forest growth and changes in the diametric distribution until 120 months, with the occurrence of individuals in 16 diametric classes. For the area of lowest productivity (S20), the diametric distribution has been practically constant since the initial projection age, indicating that in these areas growth stagnation occurred before this period (Figure 1).
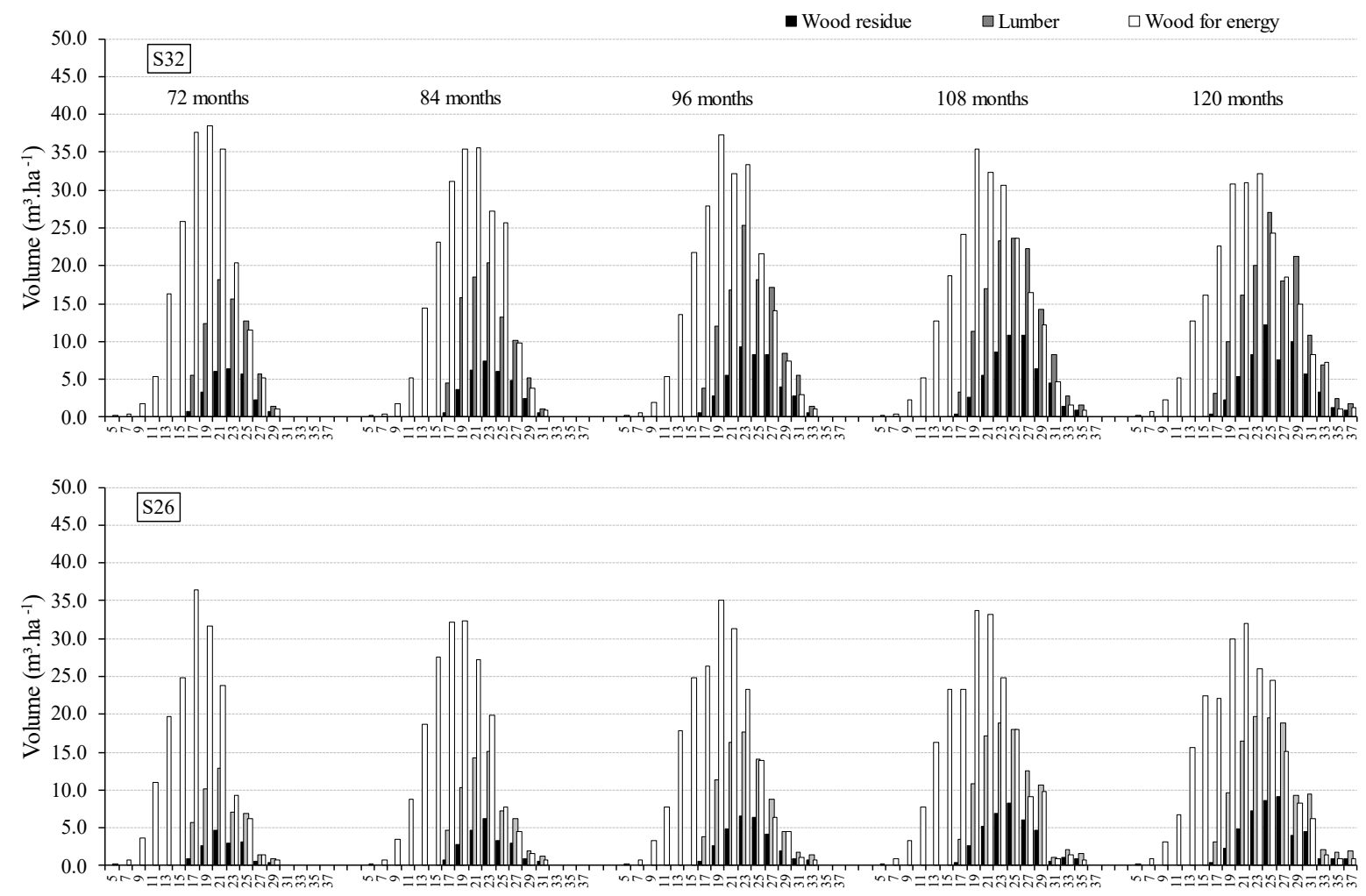

FLORESTA, Curitiba, PR, v. 51, n. 2, p. 293-302, abril/jun 2021.

Viana, L. A. et.al. 


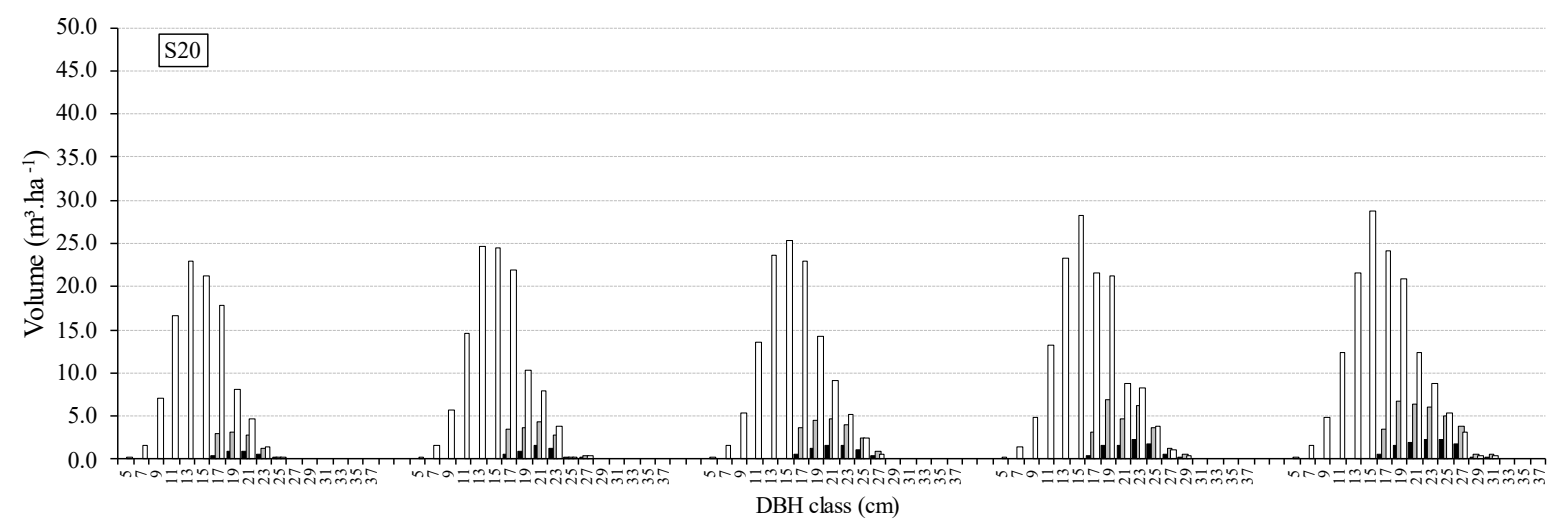

Figure 1. Volume of lumber, wood for energy and sawmill wood residue per DBH class, from non-thinned stands of the hybrid Eucalyptus urophylla $\mathrm{x}$ Eucalyptus grandis in areas of high (S32), medium (S26) and low (S20) productive capacity, considering the harvest age at 72, 84, 96, 108 and 120 months.

Figura 1. Volume de madeira serrada, de madeira para energia e de resíduo madeireiro de serraria por classe de DAP, proveniente de povoamento não desbastado do híbrido Eucalyptus urophylla x Eucalyptus grandis em áreas de alta (S32), média (S26) e baixa (S20) capacidade produtiva, considerando idades de colheita de 72, 84, 96, 108 e 120 meses.

An important difference was observed in the number and diversity of lumber pieces among the productive capacity classes of the stand. In common among the three classes, it is clear that the diversification of the pieces allows them to be obtained at 72 months, which is the lowest harvest age considered in this study.
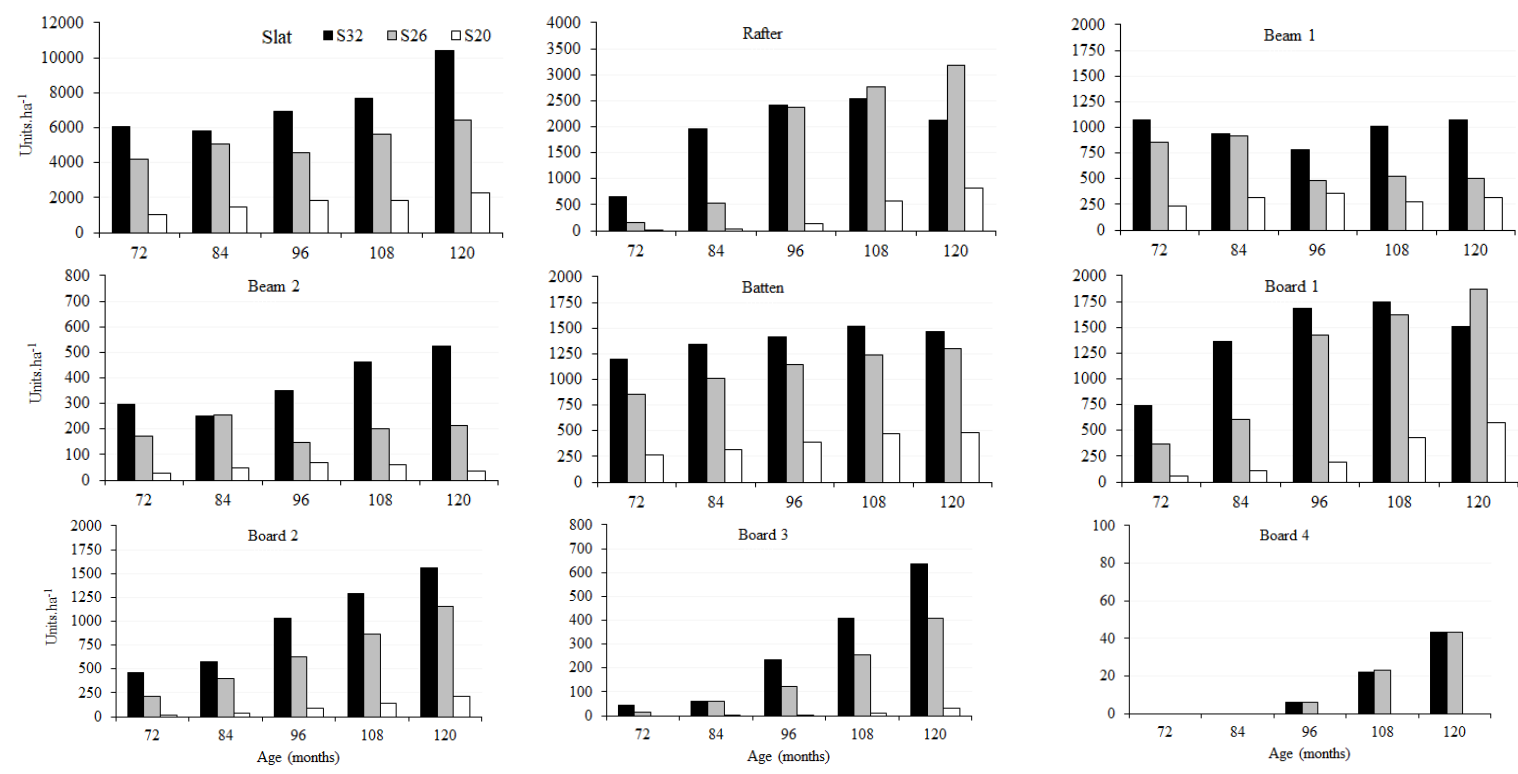

Figure 2. Number of lumber pieces obtained from non-thinned stands of the hybrid Eucalyptus urophylla $\mathrm{x}$ Eucalyptus grandis in areas of high (S32), medium (S26) and low (S20) productive capacity, considering harvest ages of 72, 84, 96, 108 and 120 months.

Figura 2. Número de peças de madeira serrada obtidas de povoamento não desbastado do híbrido Eucalyptus urophylla x Eucalyptus grandis em áreas de alta (S32), média (S26) e baixa (S20) capacidade produtiva, considerando idades de colheita de 72, 84, 96, 108 e 120 meses.

Considering the destination of wood for multiproducts, the indicators were higher at 120 months for the medium and low productivity classes. In the higher productivity class, higher NPV was obtained with the harvest at 84 months and greater BPE at 72 months, thus, in this class, the ideal harvest age was 72 months, with BPE prevailing as an indication of viability (Table 5).

If the wood is destined exclusively for energy, the most economically viable harvest option was at 72 months for the S32 and S26 classes, according to BPE. For the lower productivity class, that option was only economically viable at 84 months. 
In the S32 class, the optimal forest harvest age for energy and lumber was the same, 72 months. However, when destining the wood for multiproduct, it was possible to obtain a profit 3.7 times greater than when it is destined only for energy. For the classes S26 and S20, although the harvest of the wood for multiproduct is ideal at 120 months and for energy is more viable in the early ages of prognosis, even when harvesting wood for multiproduct at the same age as for energy, you can still profit greater than 3.8 times that obtained only with the use of wood for energy.

Table 5. Net present value (VPL) and equivalent periodic benefit (BPE) considering the use of the wood, from non-thinned stands of the hybrid Eucalyptus urophylla $\mathrm{x}$ Eucalyptus grandis under productive capacity classes (CP), for energy and lumber, at harvest age of 72, 84, 96, 108 and 120 months.

Tabela 5. Valor presente líquido (VPL) e benefício periódico equivalente (BPE) considerando a destinação da madeira de povoamento não desbastado do híbrido Eucalyptus urophylla x Eucalyptus grandis e sob diferentes classes de capacidade produtiva (CP), para energia e serraria aos 72, 84, 96, 108 e 120 meses.

\begin{tabular}{cccccccc}
\hline \multirow{2}{*}{ Usage } & \multirow{2}{*}{ Indicator } & \multirow{2}{*}{ CP } & \multicolumn{5}{c}{ Age (months) } \\
\cline { 3 - 8 } & & $\mathbf{7 2}$ & $\mathbf{8 4}$ & $\mathbf{9 6}$ & $\mathbf{1 0 8}$ & $\mathbf{1 2 0}$ \\
\hline \multirow{3}{*}{$\begin{array}{c}\text { Multiproducts } \\
\text { (lumber + energy) }\end{array}$} & \multirow{2}{*}{ VPL } & S32 & $21,084.31$ & $22,883.39$ & $22,657.67$ & $20,510.53$ & $20,948.91$ \\
& & S26 & $13,102.38$ & $14,764.06$ & $16,293.64$ & $16,827.33$ & $23,773.85$ \\
& \multirow{2}{*}{ BPE } & S20 & $1,642.38$ & $3,488.10$ & $3,034.83$ & $4,493.49$ & $5,082.82$ \\
\hline & & S32 & $4,965.19$ & $4,835.82$ & $4,382.47$ & $3,685.54$ & $3,537.79$ \\
& & S26 & $3,085.51$ & $3,120.01$ & $3,151.53$ & $3,023.70$ & $4,014.85$ \\
& S20 & 386.77 & 737.12 & 587.00 & 807.44 & 858.37 \\
\hline \multirow{2}{*}{ Energy } & \multirow{3}{*}{ VPL } & S32 & $5,635.90$ & $5,539.50$ & $5,134.04$ & $4,406.05$ & $3,458.94$ \\
& & S26 & $3,364.08$ & $3,542.34$ & $3,501.88$ & $3,208.85$ & $2,565.65$ \\
& & S20 & -791.75 & 747.44 & -873.32 & -930.43 & $-1,166.98$ \\
\hline \multirow{2}{*}{ BPE } & S32 & $1,219.13$ & $1,063.98$ & 893.40 & 705.32 & 515.48 \\
& & S26 & 727.70 & 680.38 & 609.38 & 513.67 & 382.36 \\
& & S20 & -171.27 & 143.56 & -151.97 & -148.94 & -173.91 \\
\hline
\end{tabular}

The analysis by the Monte Carlo method showed that the minimum values found for all productive classes are compatible with the project's viability, which remains even with variations in the cost of implanting the eucalyptus stand and interest rates within the range considered, when multiproduct are produced. The results indicate that in none of the situations considered in the simulations there is the possibility of occurrence of negative NPV and/or BPE (Table 6), under the conditions analyzed.

At any of the harvest ages considered, the NPV with the highest probability of occurrence would be greater than $\mathrm{R} \$ 19,000.00 /$ ha for the upper class, greater than $\mathrm{R} \$ 12,000.00 /$ ha for the middle class and greater than $\mathrm{R} \$ 1,500.00 /$ ha for the low productivity class. The BPE values with the highest probability of occurrence for classes S32 and S26 would be greater than R \$ 3,000.00/ha and less than R \$ 1,000.00/ha for class S20 (Table 6).

Table 6. Net present value (VPL) and equivalent periodic benefit (BPE) obtained by Monte Carlo simulation, using as input variables, interest rate and implementation cost of non-thinned stands of the hybrid Eucalyptus urophylla x Eucalyptus grandis in areas with different productive capacity (CP) and considering the harvest age at 72, 84, 96, 108 and 120 months for lumber production.

Tabela 6. Valor presente líquido (VPL) e benefício periódico equivalente (BPE) obtidos em simulação pelo método de Monte Carlo utilizando as variáveis de entrada taxa de juros e custo de implantação de povoamento do híbrido Eucalyptus urophylla x Eucalyptus grandis em áreas com diferentes capacidades produtivas (CP) e considerando colheita aos 72, 84, 96, 108 e 120 meses para produção de madeira serrada.

\begin{tabular}{|c|c|c|c|c|c|c|c|c|c|c|c|}
\hline \multirow{3}{*}{$\mathbf{C P}$} & \multirow{3}{*}{ Percentile } & \multicolumn{5}{|c|}{ Age (months) } & \multicolumn{5}{|c|}{ Age (months) } \\
\hline & & 72 & 84 & 96 & 108 & 120 & 72 & 84 & 96 & 108 & 120 \\
\hline & & \multicolumn{5}{|c|}{ VPL $(* R \$ 1,000.00 / h a)$} & \multicolumn{5}{|c|}{ BPE $(* R \$ 1,000.00 / h a)$} \\
\hline \multirow{7}{*}{ S32 } & 5 & 17.7 & 18.6 & 18.0 & 15.9 & 15.6 & 4.5 & 4.3 & 3.8 & 3.2 & 3.0 \\
\hline & 15 & 18.3 & 19.5 & 18.9 & 16.8 & 16.8 & 4.6 & 4.4 & 3.9 & 3.3 & 3.1 \\
\hline & 25 & 18.9 & 20.4 & 19.8 & 17.7 & 17.7 & 4.7 & 4.5 & 4.0 & 3.4 & 3.2 \\
\hline & 35 & 19.8 & 21.3 & 20.7 & 18.6 & 18.6 & 4.8 & 4.6 & 4.1 & 3.5 & 3.3 \\
\hline & 45 & 20.4 & 22.2 & 21.9 & 19.5 & 19.8 & 4.9 & 4.7 & 4.2 & 3.6 & 3.4 \\
\hline & 55 & 21.3 & 23.1 & 22.8 & 20.7 & 21.3 & 5.0 & 4.8 & 4.3 & 3.7 & 3.5 \\
\hline & 65 & 22.2 & 24.3 & 24.0 & 21.9 & 22.5 & 5.1 & 5.0 & 4.5 & 3.8 & 3.7 \\
\hline
\end{tabular}

FLORESTA, Curitiba, PR, v. 51, n. 2, p. 293-302, abril/jun 2021.

Viana, L. A. et.al.

ISSN eletrônico 1982-4688

DOI: $10.5380 /$ rf.v51 i2. 63729 


\begin{tabular}{|c|c|c|c|c|c|c|c|c|c|c|c|}
\hline & 75 & 22.8 & 25.2 & 25.2 & 23.1 & 24.0 & 5.2 & 5.1 & 4.6 & 3.9 & 3.8 \\
\hline & 85 & 23.7 & 26.1 & 26.4 & 24.3 & 25.2 & 5.3 & 5.2 & 4.7 & 4.0 & 3.9 \\
\hline & 95 & 24.6 & 27.3 & 27.6 & 25.5 & 26.7 & 5.4 & 5.3 & 4.8 & 4.2 & 4.1 \\
\hline \multirow{10}{*}{ S26 } & 5 & 10.8 & 11.7 & 13.5 & 12.9 & 17.7 & 2.7 & 2.8 & 2.7 & 2.5 & 3.3 \\
\hline & 15 & 11.4 & 12.3 & 14.1 & 13.5 & 18.9 & 2.8 & 2.9 & 2.8 & 2.6 & 3.5 \\
\hline & 25 & 11.7 & 12.9 & 15.0 & 14.4 & 20.1 & 2.9 & 3.0 & 2.9 & 2.7 & 3.6 \\
\hline & 35 & 12.3 & 13.5 & 15.6 & 15.3 & 21.3 & 2.9 & 3.0 & 3.0 & 2.8 & 3.7 \\
\hline & 45 & 12.9 & 14.1 & 16.5 & 16.2 & 22.5 & 3.0 & 3.1 & 3.1 & 2.9 & 3.9 \\
\hline & 55 & 13.2 & 15.0 & 17.4 & 17.1 & 24.0 & 3.1 & 3.2 & 3.1 & 3.0 & 4.0 \\
\hline & 65 & 13.8 & 15.6 & 18.0 & 18.0 & 25.5 & 3.1 & 3.3 & 3.2 & 3.1 & 4.2 \\
\hline & 75 & 14.4 & 16.2 & 19.2 & 18.9 & 27.3 & 3.2 & 3.4 & 3.3 & 3.2 & 4.3 \\
\hline & 85 & 15.0 & 17.1 & 20.1 & 20.1 & 29.1 & 3.3 & 3.5 & 3.4 & 3.3 & 4.5 \\
\hline & 95 & 15.6 & 17.7 & 21.0 & 21.3 & 30.6 & 3.4 & 3.6 & 3.5 & 3.4 & 4.6 \\
\hline \multirow{10}{*}{ S20 } & 5 & 0.9 & 2.1 & 1.8 & 2.7 & 3.0 & 0.2 & 0.4 & 0.4 & 0.5 & 0.5 \\
\hline & 15 & 0.9 & 2.4 & 2.1 & 3.0 & 3.3 & 0.2 & 0.4 & 0.4 & 0.6 & 0.6 \\
\hline & 25 & 1.2 & 2.7 & 2.4 & 3.3 & 3.9 & 0.3 & 0.6 & 0.4 & 0.6 & 0.7 \\
\hline & 35 & 1.2 & 3.0 & 2.4 & 3.9 & 4.2 & 0.3 & 0.6 & 0.5 & 0.7 & 0.7 \\
\hline & 45 & 1.5 & 3.3 & 2.7 & 4.2 & 4.8 & 0.3 & 0.7 & 0.5 & 0.7 & 0.8 \\
\hline & 55 & 1.5 & 3.3 & 3.0 & 4.5 & 5.1 & 0.4 & 0.7 & 0.6 & 0.8 & 0.8 \\
\hline & 65 & 1.8 & 3.6 & 3.3 & 4.8 & 5.7 & 0.4 & 0.8 & 0.6 & 0.8 & 0.9 \\
\hline & 75 & 1.8 & 3.9 & 3.6 & 5.4 & 6.0 & 0.4 & 0.8 & 0.6 & 0.9 & 1.0 \\
\hline & 85 & 2.1 & 4.5 & 3.9 & 5.7 & 6.6 & 0.4 & 0.9 & 0.7 & 0.9 & 1.0 \\
\hline & 95 & 2.1 & 4.8 & 4.2 & 6.3 & 7.2 & 0.5 & 0.9 & 0.7 & 1.0 & 1.0 \\
\hline
\end{tabular}

Interest rate of $8.0 \%$ and implementation cost of R \$2,689.50 - both varying $\pm 30 \%$.

\section{DISCUSSION}

The difference in yield observed according to the productive capacity class is explained by the sequence and quantity of procedures performed to obtain each type of wood product. For areas with higher productivity, it is possible for trees to reach larger dimensions and thus the greater number of lumber pieces can be obtained. For areas with less productive capacity, trees tend to have smaller dimensions and therefore less use in sawmill. Considering that, the greater the number of lumber pieces, the greater the need to make cuts during the sawing process, so there is a greater generation of residues compared to cutting the tree into logs for energy.

The proportion of wood destined for lumber in classes S32 and S26, aged 96 months or older, was similar to that observed by Castro et al., 2011 at 142 months, for eucalyptus stands with thinning of 25 and $35 \%$ of the basal area at 58 months. However, it must be taken into account that for the present study, although growth was projected until 120 months, there was no simulation or thinning.

The stands growth, observed from the diametric distribution, shows that the stratification by productive capacity class can contribute to making more accurate decisions about the rotation and destination of the wood produced. For any of the productive classes, it was possible to allocate wood to obtain multiproducts, however, for the areas of high and medium capacity, if the wood harvesting occurred at an age close to that in which the tendency towards stagnation in areas of low productive capacity was observed, would cause economic and technical return lower than that possible to be achieved. The dimensions of the trees would allow reduced utilization of their wood for lumber, for example, since the percentage of wood destined for that use is closely linked to the dimensions of the harvested logs (ANJOS; FONTE, 2016; CUNHA et al., 2015).

At all ages and productive capacity classes considered, it was possible to obtain lumber pieces, however, those of larger dimensions and added value were obtained predominantly in areas of greater productive capacity, which was already expected. These results corroborate the fact that the quality of the site affects productivity (FIGUEIREDO FILHO et al., 2014; DAVID et al., 2017) and consequently the quality of the logs to be sent to the sawmill.

When comparing the differences in economic indicators regarding the destination of wood, it is observed that the options for marketing multiproducts produce greater economic returns, corroborating other studies. Soares et al. (2003) compared profitability when forestry production is destined to obtain a single product and for multiproducts, and concluded that there would be greater economic profitability when destining the production of

FLORESTA, Curitiba, PR, v. 51, n. 2, p. 293-302, abril/jun 2021.

Viana, L. A. et.al.

ISSN eletrônico 1982-4688

DOI: $10.5380 /$ rf.v51 i2. 63729 
a stand for multiproducts. Campos et al. (2013) observed that the conversion of the forest into multiproducts had an average increase of $65.08 \%$ in revenue when compared to the average revenue obtained by converting the stand to a single product.

Pavan et al. (2010) found NPV values of R\$2,152.30 to R\$ 10,640.28 per hectare in eucalyptus stands whose wood was destined for energy, cellulose and lumber in Rio Grande do Sul, however, when destining the wood for production of cellulose and energy, the highest values found were $\mathrm{R} \$ 3,110.69$ and $\mathrm{R} \$ 1,668.76 / \mathrm{ha}$, respectively, with a tendency to negative values.

The estimates obtained by the Monte Carlo method as those most likely to occur are consistent with those obtained by the economic analysis, with fixed interest rates and implementation costs, in the present work. They also corroborate the results obtained by Guedes et al. (2011), who analyzed the financial viability of the reform and the management of the sprouting of eucalyptus stands, under deterministic and risk conditions. Using the Monte Carlo method, the authors observed that in the several options for reform and coppice studied, financial viability has always occurred, reducing uncertainties and, consequently, increasing security for decision making.

Studies such as those by Castro et al. (2007), Coelho Júnior et al. (2008) and Viana et al. (2013) highlighted that the application of the Monte Carlo method considers variations that may arise during the development of the forestry project. According to Coelho Júnior et al. (2008) if, based on the Monte Carlo method, the decisions taken are more than $50 \%$ likely to be correct, they will already be higher than those made based on traditional methods of financial evaluation.

Obtaining multiproducts from wood can provide a reduction in the risk of financial losses, as it provides flexibility in the commercialization of products. However, the viability of the forestry project is dependent on the correct planning of technical issues, such as the productivity of the site, and economic issues, such as interest rates and production costs.

\section{CONCLUSIONS}

The analyzes carried out lead to the conclusion that:

- The quantity of different types of products obtained and the wood yield depends on the productive capacity class and age of the stand.

- The destination of the wood for multiproducts is the most viable option, regardless of the productive capacity class.

\section{REFERENCES}

ANJOS, R. A. M.; FONTE, A. P. N. Rendimento de madeira serrada de espécies de Eucalyptus. Revista de Ciências Agroveterinárias, Lages, v. 16, n. 1, p. 26-32, 2017.

ASSIS, A. L.; SCOLFORO, J. R. S.; MELLO, J. M.; OLIVEIRA, A. D. Avaliação de modelos polinomiais nãosegmentados na estimativa de diâmetros e volumes comerciais de Pinus taeda. Ciência Florestal, Santa Maria, v. 12 , n. 1 , p. $89-107,2002$.

CAMPOS, J. C. C.; LEITE, H. G. Mensuração florestal: perguntas e respostas. 5.ed. Viçosa: UFV, 2017. 636p.

CAMPOS, B. P. F.; BINOTI, D. H. B.; SILVA, M. L.; LEITE, H. G.; BINOTI, M. L. M. S. Conversão de árvores em multiprodutos da madeira utilizando programação inteira. Revista Árvore, Viçosa, v. 37, n. 5, p. 881 - 887, 2013.

CASTRO, R. V. O.; LEITE, H. G.; NOGUEIRA, G. S.; SOARES, C. P. B.; ARAÚJO JÚNIOR, C. A.; CASTRO, A. F. N. M.; CRUZ, J. P.; SANTOS, F. L.; SOUZA, C. C. Avaliação econômica de um povoamento de eucalipto desbastado e destinado a multiprodutos da madeira. Scientia Forestalis, Piracicaba, v. 39, n. 91 , p. 351 - 357 , 2011.

CASTRO, R. R.; SILVA, M. L.; LEITE, H. G.; OLIVEIRA, M. L. R. Rentabilidade econômica e risco na produção de carvão vegetal. Cerne, Lavras, v. 13, n. 4, p. 353 - 359, 2007.

COELHO JÚNIOR, L. M.; REZENDE, J. L. P.; OLIVEIRA, A. D.; COIMBRA, L. A. B.; SOUZA, A. N. Análise de investimento de um sistema agroflorestal sob condição de risco. Cerne, Lavras, v. 14, n. 4, p. 368 - $378,2008$.

CUNHA, A. B.; FRANÇA, M. C.; ALMEIDA, C. C. F.; GORSKI, L.; CRUZ, R. C.; SANTOS, D. Avaliação do rendimento em madeira serrada de Eucalyptus benthamii e de Eucalyptus grandis por meio do desdobro tangencial e radial. Floresta, Curitiba, v. 45, n. 2, p. 241 - 250, 2015.

FLORESTA, Curitiba, PR, v. 51, n. 2, p. 293-302, abril/jun 2021

Viana, L. A. et.al. 
DAVID, H.C.; PÉLLICO NETTO, S.; ARCE, J. E.; CORTE, A. P. D.; MARINHESKI FILHO, A.; ARAÚJO, E. J. G. Efeito da qualidade do sítio e do desbaste na produção de pinus. Floresta e Ambiente, Seropédica, v. 24, 2017.

DEMOLINARI, R. A.; SOARES, C. P. B.; LEITE, H. G.; SOUZA, A. L. Crescimento de plantios clonais de eucalipto não desbastados na região de Monte Dourado (PA). Revista Árvore, Viçosa, v. 31, n. 3, p. 503 - 512, 2007.

FIGUEIREDO FILHO, A.; KOHLER, S. V.; FELDE, J. L.; DIAS A. N. Dinâmica do afilamento do tronco e da produção de madeira em plantios de Araucaria angustifolia. Cerne, Lavras, v. 20, n. 4, p. 595 - 603, 2014.

FOLMANN, W. T.; MIRANDA, G. M.; DIAS, A. N.; MORO, F. C.; FERNANDEZ, M. L. Q. Viabilidade de projetos florestais em três regimes de manejo na mesorregião centro-oriental do Paraná. Floresta, Curitiba, v. 44, n. 1, p. $153-160,2014$.

GUEDES I. C. L.; COELHO JÚNIOR L. M.; OLIVEIRA A. D.; MELLO J. M.; REZENDE J. L. P.; SILVA C. P. C. Economic analysis of replacement regeneration and coppice regeneration eucalyptus stands under risk conditions. Cerne, Lavras, v. 17, n. 3, p. 393 - 401, 2011.

IBÁ - INDÚSTRIA BRASILEIRA DE ÁRVORES. Anuário Estatístico IBÁ 2017. Brasília. 2017. 80 p.

LEITE, H. G.; CAMPOS, J. C. C.; PAULA JÚNIOR, G. G. P. Emprego de um modelo de programação dinâmica para conversão de troncos em multiprodutos da madeira. Revista Árvore, Viçosa, v. 19, n. 4, p. 447 - 465, 1995.

LUSTOSA JÚNIOR, I. M.; LIMA, M. B. O.; NASCIMENTO, B. G.; MEIRA JÚNIOR, M. S.; CASTRO, R. V. O. Modelos de afilamento e otimização de multiprodutos de um povoamento de Eucalyptus não desbastado. Revista de Agricultura Neotropical, Cassilândia, v. 4, Suplemento 1, p. 59 - 65, 2017.

MARTINS, F. B.; SOARES, C. P. B.; SILVA, G. F. Individual tree growth models for eucalyptus in northern Brazil. Scientia Agricola, v. 71, n. 3, p. 212-225, 2014.

PAVAN, J. A.; ALVES, T. W.; SOUZA, M. A. Viabilidade econômica da produção de eucaliptos no Rio Grande do Sul. ABCustos, São Leopoldo, v. 5, n. 1, p. 92 - 127, 2010.

REZENDE, J. L. P.; OLIVEIRA, A. D. Análise econômica e social de projetos florestais. Viçosa: Ed. UFV, 3 ed. 2013, 385 p.

SILVA, M. L.; RESENDE, J. L. P.; LIMA JÚNIOR, V. B.; CORDEIRO, S. A.; COELHO JÚNIOR, L. M. Métodos do cálculo de custo da terra na atividade florestal. Cerne, Lavras, v. 14, n. 1, p. 75 - 81, 2008.

SOARES, T. S.; VALE, A. B.; LEITE, H. G.; MACHADO, C. C. Otimização de multiprodutos em povoamentos florestais. Revista Árvore, Viçosa, v. 27, n. 6, p. 811 - 820, 2003.

STAPE, J. L.; BINKLEY, D.; RYAN, M. G.; FONSECA, S.; LOOS, R.; TAKAHASHI, E. N.; SILVA, C. R; SILVA, S.; HAKAMADA, R.; FERREIRA, J. M.; LIMA, A. M.; GAVA, J. L.; LEITE, F. P.; SILVA, G.; ANDRADE, H.; ALVES, J. M. The Brazil Eucalyptus Potential Productivity Project: influence of water, nutrients and stand uniformity on wood production. Forest Ecology and Management, Amsterdam, v. 259, p. 1686 - 1694, 2010.

VIANA, L. A., JOAQUIM, M. S.; SOUZA, A. N.; SOUZA; SANCHES, K. L.; CAMELO, A. P. S. Método Monte Carlo aplicado em florestas energéticas. Enciclopédia Biosfera, Goiânia, v. 9, n. 17, p. 1883 - 1897, 2013. 